\title{
The state of carotid artery wall in hypertensive patients with gout based on the study of inflammatory markers
}

\author{
H. P. Kuzmina ${ }^{A, E, F}$, O. M. Lazarenko $\mathbb{D} * A, B, C, D$
}

Dnipro State Medical University, Kryvyi Rih, Ukraine

A - research concept and design; B - collection and/or assembly of data; C - data analysis and interpretation; D - writing the article;

$\mathrm{E}$ - critical revision of the article; $\mathrm{F}$ - final approval of the article

Key words: hypertension, gout, markers of inflammation, intima-media complex, vascular wall.

\section{Zaporozhye} medical journal 2021; 23 (5), 608-613

*E-mail: lazerhelga1988@gmail. com
The aim. To analyze the frequency of atherosclerotic lesions of the carotid arteries and association with the lipid metabolism and inflammatory markers in hypertensive patients with gout.

Materials and methods. 122 patients with hypertension aged 30 to 65 years were examined (mean age $(56.0(47.0 ; 62.0))$, including 104 men ( $85.2 \%$ ) and 18 women (14.8\%). Group 1 included 72 hypertensive patients with gout; group 2 - 50 hypertensive patients without gout; group $3-20$ gout patients without hypertension. Serum levels of high sensitivity C-reactive protein were detected by enzyme-linked immunosorbent assay. Serum ferritin levels were measured using electrochemiluminescent detection. The patients underwent carotid artery ultrasound according to standard methods.

Results. The duration of gout exacerbation and the pain intensity evaluated with the visual analog scale (VAS) $(P<0.01)$ were significantly higher in group 1, than those in group $3(P<0.01)$. Serum ferritin levels were $2.6(P<0.01)$ times higher in group 1 than those in group 2. In patients with gout, the levels of ferritin were significantly 2.1 times higher, than in group $2(P<0.01)$. The levels of hsCRP in patients of group 1 were 3.1 times higher than those in group $2(P<0.01)$. The proportion of patients with intima-media complex (IMC) thickness $\geq 0.9 \mathrm{~mm}$ was higher in group 1 than in groups $2\left(X^{2}=4.58, P<0.05\right)$ and $3\left(X^{2}=24.96\right.$, $P<0.01)$. In the structure of plaques, isoechoic were significantly more often seen among group 1 patients as compared to group $3\left(X^{2}=6.56, P<0.01\right)$, and hyperechoic - as compared to group $2\left(X^{2}=4.63, P<0.05\right)$. Hypoechoic plaques were detected in groups 1 and 2 with similar frequency $(P>0.05)$. This type of plaque was associated with a high risk of cerebrovascular events. In the patients with arterial hypertension and gout, a significant moderate positive correlation was found between the IMC thickness and the serum uric acid level $\left(r_{s}=0.46, P<0.01\right)$, hsCRP $\left(r_{s}=0.33, P<0.01\right)$, age $\left(r_{s}=0.33 ; P<0.01\right)$, duration of gout $\left(r_{s}=0.27, P<0.05\right)$ and VAS $\left(r_{s}=0.39, P<0.01\right)$; the level of hSCRP was correlated with the presence of atherosclerotic plaques $(\tau=+0.64, \mathrm{P}<0.05)$.

Conclusions. The combination of hypertension with gout in patients was associated with a high incidence of IMC thickness $\geq 0.9 \mathrm{~mm}$ and atherosclerotic plaques, more severe disorders of purine and lipid metabolism, increased inflammatory markers (ferritin and hsCRP), that should be considered not only in the aspect of chronic inflammation, but also as a part of the disease.
Киючові слова: артеріальна гіпертензія, подагра, маркери запалення, комплекс інтимамедіа, судинна стінка.

Запорізький медичний журнал 2021. T. 23, № 5(128) C. $608-613$

\section{Стан судинної стінки сонних артерій на основі вивчення маркерів запалення в пацієнтів з артеріальною гіпертензією, поєднаною з подагрою}

\section{Г. П. Кузьміна, О. М. Аазаренко}

Мета роботи -проаналізувати частоту атеросклеротичного ураження сонних артерій та асоціацію з показниками ліпідного обміну, маркерами запалення в пацієнтів з артеріальною гіпертензією, поєднаною з подагрою.

Матеріали та методи. Обстежили 122 пацієнтів з артеріальною гіпертензією віком від 30 до 65 років (середній вік - 56,0 $(47,0 ; 62,0)): 104(85,2 \%)$ чоловіків і 18 (14,8 \%) жінок. У групі 1 - 72 пацієнти з артеріальною гіпертензією, що поєднана 3 подагрою; у групі 2 -50 хворих на артеріальну гіпертензію без подагри; у групі 3 - 20 пацієнтів із подагрою без артеріальної гіпертензії. Рівень високочутливого С-реактивного протеїну в сироватці крові визначали за допомогою імуноферментного аналізу, рівень феритину у крові - імунохімічним методом з електрохемілюмінесцентною детекцією. Пацієнтам виконували ультразвукове дослідження каротидних судин за стандартною методикою.

Результати. Тривалість загострення подагри, інтенсивність больового синдрому за візуальною аналоговою шкалою (ВАШ) $(\mathrm{p}<0,01)$ вірогідно більші у групі 1, ніж у групі 3 ( $p<0,01)$. Рівень феритину у 2,6 раза ( $p<0,01)$ вищий у групі 1 порівняно з показником групи 2. У хворих на подагру рівень феритину у 2,1 раза вищий, ніж у групі $2(p<0,01)$. Показник високочутливого С-реактивного протеїну (вчСРП) у пацієнтів групи 1 в 3,1 раза вищий щодо показника групи 2 ( $<<0,01)$. Частка пацієнтів із товщиною комплексу інтима-медіа (КІM) $\geq 0,9$ мм найбільша у групі 1 порівняно з групами $2\left(X^{2}=4,58\right.$, $p<0,05)$ і $3\left(x^{2}=24,96, p<0,01\right)$. У хворих групи 1 вірогідно частіше порівняно з групою 3 у структурі бляшок переважає ізоехогенна $\left(X^{2}=6,56, p<0,01\right)$, а щодо групи 2 - гіперехогенна $\left(X^{2}=4,63, p<0,05\right)$. У групах 1 і 2 з однаковою частотою ( $p>0,05)$ виявляли гіпоехогенний тип бляшки, який пов'язаний із високим ризиком цереброваскулярних подій. У пацієнтів з артеріальною гіпертензією, що поєднана з подагрою, виявили вірогідний позитивний кореляційний зв'язок помірної сили між товщиною КІМ і рівнем сечової кислоти крові $\left(r_{s}=0,46, p<0,01\right)$, вчСРП $\left(r_{s}=0,33, p<0,01\right)$, віком $\left(r_{s}=0,33, p<0,01\right)$, тривалістю подагри $\left(r_{s}=0,27, p<0,05\right)$ та оцінкою за ВАШ $\left(r_{s}=0,39, p<0,01\right)$; рівень вчСРП корелює з наявністю атеросклеротичних бляшок $(\tau=+0,64, p<0,05)$.

Висновки. Поєднання артеріальної гіпертензії та подагри асоціюється з високою частотою товщини КІM $\geq 0,9$ мм та атеросклеротичних бляшок, вираженішими порушеннями пуринового та ліпідного обмінів, підвищенням маркерів запалення (феритин і вчСРП), що слід розглядати не лише в аспекті хронічного запального процесу, але і як складову захворювання. 


\section{Состояние сосудистой стенки сонных артерий на основе изучения маркеров воспаления у пациентов с артериальной гипертензией в сочетании с подагрой}

\section{А. П. Кузьмина, О. Н. Казаренко}

Цель работы -проанализировать частоту атеросклеротического поражения сонных артерий и ассоциации с показателями липидного обмена, маркерами воспаления у пациентов с артериальной гипертензией в сочетании с подагрой.

Материалы и методы. Обследовали 122 пациента с артериальной гипертензией в возрасте от 30 до 65 лет (средний возраст - 56,0 (47,0; 62,0)): 104 (85,2 \%) мужчины и 18 (14,8 \%) женщин. В группу 1 включили 72 пациента с артериальной гипертензией в сочетании с подагрой, группу $2-50$ больных артериальной гипертензией без подагры; группу $3-20$ пациентов с подагрой без артериальной гипертензии. Уровень высокочувствительного С-реактивного протеина в сыворотке крови определяли с помощью иммуноферментного анализа, уровень ферритина в крови - иммунохимическим методом с электрохемилюминесцентной детекцией. Пациентам выполнено ультразвуковое исследование каротидных сосудов по стандартной методике.

Результаты. Длительность обострения подагры, интенсивность болевого синдрома по визуальной аналоговой шкале (ВАШ) $(p<0,01)$ значительно выше в группе 1, чем в группе 3 ( $p<0,01)$. Уровень ферритина в 2,6 раза $(p<0,01)$ выше в группе 1 по сравнению с показателями группы 2. У больных подагрой уровень ферритина в 2,1 раза выше, чем в группе 2 ( $\mathrm{p}<0,01)$. Показатель высокочувствительного С-реактивного протеина (вчСРП) у пациентов группы 1 в 3,1 раза выше относительно показателя группы $2(p<0,01)$. Доля пациентов с толщиной комплекса интима-медиа (КИМ) $\geq 0,9$ мм наибольшая в группе 1 по сравнению с группами $2\left(X^{2}=4,58, p<0,05\right)$ и $3\left(X^{2}=24,96, p<0,01\right)$. У больных группы 1 достоверно чаще по сравнению с группой 3 в структуре бляшек преобладает изоэхогенная $\left(X^{2}=6,56, p<0,01\right)$, а относительно группы 2 -гиперэхогенная $\left(X^{2}=4,63, p<0,05\right)$. В группах 1 и 2 с одинаковой частотой $(p>0,05)$ регистрировали гипоэхогенный тип бляшки, который связан с высоким риском цереброваскулярных событий. У пациентов с артериальной гипертензией в сочетании с подагрой установлена достоверная положительная корреляционная связь умеренной силы между толщиной КИМ и уровнем мочевой кислоты крови $\left(r_{s}=0,46, p<0,01\right)$, вчСРП $\left(r_{s}=0,33, p<0,01\right)$, возрастом $\left(r_{s}=0,33, p<0,01\right)$, продолжительностью подагры $\left(r_{s}=0,27, p<0,05\right)$ и оценкой по ВАШ $\left(r_{s}=0,39, p<0,01\right)$; уровень вчСРП коррелирует с наличием атеросклеротических бляшек $(\tau=+0,64, \mathrm{p}<0,05)$.

Выводы. Сочетание артериальной гипертензии и подагры у пациентов ассоциируется с высокой частотой толщины КИМ $\geq 0,9$ мм и атеросклеротических бляшек, более выраженными нарушениями пуринового и липидного обменов, повышением маркеров воспаления (ферритин и вчСРП), что следует рассматривать не только в аспекте хронического воспалительного процесса, но и как составную часть заболевания.

According to the recommendations of the American Heart Association, the intima-media complex (IMC) thickness of the carotid arteries, along with other vascular markers, is of a great importance in the primary prevention of cardiovascular complications. Many studies have shown an association between IMC and high importance of major vascular risk factors for circulatory disorders: dyslipidemia and hypertension. The IMC thickness determines the individual severity of cardiovascular diseases [1,2].

Hyperuricemia, which in some cases leads to the development of gout, is involved in the pathogenesis of hypertension and atherosclerosis [1]. Epidemiological studies revealed the relationship between hyperuricemia and atherosclerotic vascular disease, and serum uric acid (UA) levels, making it possible to predict cardiovascular events and mortality in women and men [2].

Atherosclerotic changes are based on three mechanisms (vascular lipid infiltration, endothelial dysfunction and chronic inflammation), which are present in hypertension and gout; a predictor of future cardiovascular events is C-reactive protein (CRP) [3].

Atherosclerosis has a long preclinical phase. Early detection of atherosclerotic changes using noninvasive methods of examination can help identify individuals at risk of atherosclerotic clinical event [4]. In recent decades, there has been a growing interest in the early detection and assessment of subclinical atherosclerosis based on the detection of biomarkers [5].

According to the latest scientific findings, researchers have found an interaction between traditional risk factors and risk factors for the development of atherosclerotic plaques in the carotid artery. The rate of atherosclerotic plaque formation was significantly lower in patients with essential hypertension and hyperlipidemia, who received lipid-lowering drugs and antihypertensive treatment for 24 months. Blood pressure (BP) levels were significantly elevated in patients with newly diagnosed internal carotid artery stenosis (ICA) $>50 \%$ compared to healthy controls. Serum CRP was significantly increased, and total bilirubin was significantly decreased in patients with hypertension and atherosclerosis of the carotid arteries, compared to the patients with hypertension and without atherosclerosis. Early- and end-stage calcifications of carotid lesions were significantly increased in patients with chronic kidney disease (CKD) compared to those in patients without CKD. Finally, serum fibrinogen and CRP levels were significantly elevated in patients with carotid artery stenosis $>70 \%$ and CKD compared to those without CKD [6].

Previous studies have shown an association between the risk of cerebrovascular events and ICA stenosis and a correlation with its degree. However, recent studies report that low degrees of carotid stenosis can also cause ischemic cerebrovascular events. This indicates that in addition to the size of atherosclerotic plaques and the degree of stenosis, other characteristics of plaques, especially their composition, might be related to the risk of cerebrovascular events. A higher lipid content in plaques, especially low-density lipoprotein cholesterol (LDL cholesterol), which depends on plasma levels, is a major risk factor for atherosclerotic plaque instability. Serum LDL cholesterol and total cholesterol (TC) were associated with acutely symptomatic carotid plaques. Determining the inflammatory process helps to
Ключевые слова: артериальная гипертензия, подагра, маркеры воспаления, комплекс интимамедиа, сосудистая стенка.

\section{Запорожский} медицинский журнал. 2021. T. 23, № 5(128). C. $608-613$ 
identify unstable atherosclerotic lesions that are a source of complications. The migration of circulating monocytes into the vessel wall is a key event in initiating the formation of atherosclerotic plaque. This process is mediated by the expression of adhesion molecules in response to stimulation or damage to the endothelium caused by hypertension, smoking, gout [7].

Despite the importance of this problem, today there is not enough work to study the nature of carotid artery lesions in hypertensive patients with gout.

\section{Aim}

To analyze the frequency of atherosclerotic lesions of the carotid arteries and association with the lipid metabolism and inflammatory markers in hypertensive patients with gout.

\section{Materials and methods}

A dynamic examination and management of patients was conducted on the clinical basis of the Department of Therapy, Cardiology and Family Medicine of the Faculty of Postgraduate Education of Dniprovskyi State Medical University - Municipal Enterprise "Kryvyi Rih City Clinical Hospital No. 2, Kryvyi Rih City Council”. Outpatient selection of patients was carried out on the basis of "Primary Health Care Center No. 4, Kryvyi Rih City Council" in the period from 2016 to 2019.

A permission for the research were obtained from the Commission on Biomedical Ethics of Dnipropetrovsk State Medical University (protocol No. 1 dated 16.01.2017), which concluded that the work met generally accepted moral standards, requirements for rights, interests and personal dignity of the studied participants.

122 patients with hypertension aged 30 to 65 years were examined (mean age $(56.0(47.0 ; 62.0))$, including 104 men (85.2\%) and 18 women (14.8\%). Group 1 included 72 hypertensive patients with gout; group $2-50$ hypertensive patients without gout; group $3-20$ gout patients without hypertension.

The diagnosis of hypertension was established in accordance with the recommendations of the European Society of Hypertension and the European Society of Cardiology (2018) [8]. The diagnosis of gout was established according to the criteria of the American College of Rheumatology (ACR) and the European League Against Rheumatism (EULAR, 2015) $[9,10]$.

Inclusion criteria: male and female aged 30 to 65 years, who gave an informed consent to participate in the study; hypertensive patients with gout; hypertensive patients without gout; gout patients without hypertension.

Exclusion criteria: patients who did not give the informed consent to participate in the study; patients with autoimmune, oncological, mental diseases, hepatitis, tuberculosis, HIV infection; patients with coronary heart disease, arrhythmias, III degree hypertension, IIA-III degree heart failure, CKD; patients with other crystal arthropathies; patients with alcohol or drug abuse.

Biochemical parameters of the lipid profile were determined in the serum by enzymatic method on an automatic biochemical analyzer Humastar 300 (HUMAN GmbH, Italy, 2011) using reagents Human (Italy). The concentration of
LDL cholesterol (mmol/l) was calculated by the formula (W. Friedewald et al., 1972).

Serum levels of high sensitivity CRP (hsCRP) were detected by enzyme-linked immunosorbent assay using reagents "CRP High Sensitivity" (Immulite Siemens, USA) on an automatic immunochemiluminescent analyzer Immulite 1000 (Siemens, USA, 2015).

Serum ferritin levels were measured by electrochemiluminescent detection using an automatic Cobas e411 analyzer (Roche Diagnostics GmbH \& Hitachi, Japan, 2011) and a test system "Ferritin" (Roche Diagnostics, Germany).

The patients underwent carotid artery ultrasound (US) with a linear sensor with a frequency of $5-10 \mathrm{MHz}$ according to standard methods on a device ESAOTE MyLab Class C (Esaote S.p.A., Italy, 2012). According to the recommendations of the European Society of Cardiology (2013), the diagnostic criterion for IMC thickening was considered to be $\geq 0.9 \mathrm{~mm}$, the atherosclerotic plaque presence was recognized at local IMC thickening $>1.5 \mathrm{~mm}$, thickening $>50.0 \%$ or $0.5 \mathrm{~mm}$ according to the adjacent areas of IMC. The structure of atherosclerotic plaque and the degree of stenosis of brachiocephalic vessels were determined (stenosis $>50.0 \%$ was considered significant).

Methods of statistical analysis were used for statistical processing of the study materials: verification of normal distribution of quantitative indicators - using the Shapiro-Wilk test; assessment of significant differences between the mean values for quantitative characteristics with a normal distribution - with the Student's t-test; assessment of significant differences between the mean values for non-normally distributed quantitative characteristics - with the Mann-Whitney $U$ test for two independent samples; the significant differences between categorical variables - using Pearson's Chi-square $\left(X^{2}\right)$ test with the Yates correction for values close to 0 or 100 , and the McNemar's test for paired categorical variables. Quantitative comparative assessment of two normally distributed paired samples was performed by the Student's t-test for dependent groups; of non-normally distributed - by the Wilcoxon test.

Comparison of three or more independent groups with non-normal distribution for quantitative traits was performed using Kruskal-Wallis tests (nonparametric analysis of variance) with Dunn's correction in a pairwise comparison of samples. The equality of the three general variances was determined using the Levene test.

Correlation analysis was performed by calculating the Pearson correlation coefficient (r), Spearman rank correlation $\left(r_{s}\right)$. The Kendall rank correlation coefficient $(\tau)$ was used to determine the relationship between qualitative and quantitative values.

The results of descriptive statistics included indicators for the normally distributed quantitative characteristic: mean (M), standard deviation (SD); for the non-normally distributed quantitative traits: median (Me) and interquartile range $\left(Q_{25} ; Q_{75}\right)$.

The critical value of the significance level $(P)$ was taken as $<5.0 \%(P<0.05)$. Statistical analysis was performed using the Microsoft Excel software package (Microsoft Office 2010) and Statistica 6.1 (StatSoft Inc., serial No. AGAR909E415822FA). 


\section{Results}

General characteristics of the groups are shown in Table 1. The groups were representative in age and sex.

The duration of gout exacerbation and the pain intensity evaluated with the visual analog scale (VAS) $(P<0.01)$ were significantly higher in hypertensive patients with gout compared with those in gout patients without hypertension $(P<0.01)$, which may indicate a more severe course of gout when combined with hypertension.

The patients in group 1 were characterized by a more serious lipid metabolism disorders: higher TC levels by $10.0 \%$ $(P<0.01)$ as compared to group 3; higher triglyceride $(T G)$ levels by $53.3 \%(P<0.01)$ and $35.3 \%(P<0.01)$ in comparison with groups 2 and 3 , respectively. The LDL cholesterol level was $3.1 \%(P<0.05)$ and $6.5 \%(P<0.01)$ higher in hypertensive patients with gout than in hypertensive patients and gout patients, respectively. The lowest level of high-density lipoprotein cholesterol (HDL cholesterol) were found in group 1 patients $-8.3 \%(P<0.01)$ lower than in groups 2 and $3(P<0.05)$. It should be noted that the incidence of hypercholesterolemia and hypertriglyceridemia was $30.6 \%$ (22) and $36.1 \%$ (26) significantly higher, respectively, in group 1 patients $(P<0.05)$.

The analysis results showed $37.6 \%$ significantly higher $(P<0.01)$ serum UAlevel in group 1 than that in group 2 .

Serum ferritin levels were $2.6(P<0.01)$ times higher in group 1, that those in group 2 . In patients with gout, the level of ferritin were significantly 2.1 times higher than in group 2 $(P<0.01)$. There were no significant differences in serum ferritin levels between groups 1 and $3(P>0.05)$ indicating the important role of this marker in gout.

The hsCRP levels in patients of group 1 were 3.1 times higher than those in group $2(P<0.01)$. In addition, the levels of hsCRP in group 3 were found to be 2.9 times $(P<0.01)$ higher than those in group 2 , but without differences from group $1(P>0.05)$, showing the important role of this inflammatory marker in gout.

According to the data analysis of extracranial vessel US examination, it was found that the mean value of IMC thickness in group 1 was $1.10(1.00 ; 1.20) \mathrm{mm}$, in group $2-1.00(0.80 ; 1.10) \mathrm{mm}$, in group $3-0.80(0.80 ; 1.20)$ $\mathrm{mm}$. The indicator in group 1 was significantly higher than that in groups $2(P<0.01)$ and $3(P<0.05)$ by $10.0 \%$ and $37.5 \%$, respectively.

In $65(90.3 \%)$ patients of group 1, the IMC thickness was $\geq 0.9 \mathrm{~mm}$, in $7(9.7 \%)-<0.9 \mathrm{~mm}$. Among patients of group 2, $37(74.0 \%)$ with IMC thickness $\geq 0.9 \mathrm{~mm}$ and $13(26.0 \%)$ with thickness $<0.9 \mathrm{~mm}$ were found. Group 3 patients were distributed as follows: the thickness of the IMC were $\geq 0.9 \mathrm{~mm}$ in $7(35.0 \%),<0.9 \mathrm{~mm}-$ in 13 $(65.0 \%)$ (Table 2).

The proportion of patients with IMC thickness $\geq 0.9 \mathrm{~mm}$ was greater in group 1 than that in groups $2\left(X^{2}=4.58\right.$, $P<0.05)$ and $3\left(X^{2}=24.96, P<0.01\right)$.

The detection frequency of atherosclerotic plaques and their echogenic structure in the studied groups were analyzed (Table 3).

In group 1, plaques were found in $53(73.6 \%)$ patients, in group 2 - in $23(46.0 \%)$ patients and in group 3 - in 7 $(35.0 \%)$. In group 1, the frequency of plaque detection were significantly higher than in groups $2\left(X^{2}=8.44, P<0.01\right)$ and $3\left(X^{2}=8.66, P<0.01\right)$.
Table 1. General and clinical characteristics of the studied groups, M (SD), $\operatorname{Me}\left(Q_{25} ; Q_{75}\right), \mathrm{n}(\%)$

\begin{tabular}{|c|c|c|c|}
\hline $\begin{array}{l}\text { Indicator, units of } \\
\text { measurement }\end{array}$ & Group $1(n=72)$ & Group $2(n=50)$ & Group $3(n=20)$ \\
\hline Sex: male, n (\%) & $65(90.3)$ & $\begin{array}{l}39(78.0) \\
P_{1-2}>0.05\end{array}$ & $\begin{array}{l}19(95.0) \\
P_{1-3}>0.05 \\
P_{2-3}>0.05\end{array}$ \\
\hline Age, years & $55.0(47.0 ; 60.0)$ & $\begin{array}{l}57.0(46.0 ; 64.0) \\
P_{1-2}>0.05\end{array}$ & $\begin{array}{l}50.5(9.7) \\
P_{1-3}>0.05 \\
P_{2-3}>0.12\end{array}$ \\
\hline Duration of gout, years & $4.0(2.5 ; 7.0)$ & - & $\begin{array}{l}5.2(2.7) \\
P_{1-3}>0.05\end{array}$ \\
\hline $\begin{array}{l}\text { Number of gout exacerbations } \\
\text { per year }\end{array}$ & $4.0(3.0 ; 4.0)$ & - & $\begin{array}{l}3.0(2.0 ; 4.0) \\
\mathrm{P}_{1-3}>0.05\end{array}$ \\
\hline $\begin{array}{l}\text { Duration of gout exacerbation, } \\
\text { days }\end{array}$ & $13.0(12.0 ; 15.5)$ & - & $\begin{array}{l}10.0(9.0 ; 11.5) \\
P_{1-3}<0.01\end{array}$ \\
\hline $\begin{array}{l}\text { The pain intensity evaluated } \\
\text { with the VAS, } \mathrm{mm}\end{array}$ & $35.0(30.0 ; 50.0)$ & - & $\begin{array}{l}25.8(11.6) \\
P_{1-3}<0.01\end{array}$ \\
\hline Total cholesterol, mmol/L & $5.5(5.4 ; 5.8)$ & $\begin{array}{l}5.4(1.3) \\
P_{1-2}>0.05\end{array}$ & $\begin{array}{l}5.0(0.3) \\
P_{1-3}<0.01 \\
P_{2-3}>0.05\end{array}$ \\
\hline Triglycerides, $\mathrm{mmol} / \mathrm{L}$ & $2.3(1.7 ; 2.3)$ & $\begin{array}{l}1.5(1.2 ; 2.3) \\
P_{1-2}<0.01\end{array}$ & $\begin{array}{l}1.7(1.7 ; 1.8) \\
P_{1-3}<0.01 \\
P_{2-3}>0.05\end{array}$ \\
\hline $\begin{array}{l}\text { Low-density lipoprotein } \\
\text { cholesterol, mmol/L }\end{array}$ & $3.3(3.3 ; 3.5)$ & $\begin{array}{l}3.2(0.9) \\
P_{1-2}<0.05\end{array}$ & $\begin{array}{l}3.1(3.1 ; 3.2) \\
P_{1-3}<0.01 \\
P_{2-3}>0.05\end{array}$ \\
\hline $\begin{array}{l}\text { High-density lipoprotein } \\
\text { cholesterol, } \mathrm{mmol} / \mathrm{L}\end{array}$ & $1.10(1.00 ; 1.20)$ & $\begin{array}{l}1.20(1.10 ; 1.40) \\
P_{1-2}<0.01\end{array}$ & $\begin{array}{l}1.20(1.20 ; 1.30) \\
P_{1-3}<0.05 \\
P_{2-3}>0.05\end{array}$ \\
\hline Serum uric acid, $\mu \mathrm{mol} / \mathrm{L}$ & $462.3(122.5)$ & $\begin{array}{l}336.0(278.0 ; 370.0) \\
P_{1-2}<0.01\end{array}$ & $\begin{array}{l}455.5(172.7) \\
P_{1-3}>0.05 \\
P_{2-3}<0.01\end{array}$ \\
\hline Ferritin, ng/mL & $344.0(196.5 ; 389.0)$ & $\begin{array}{l}130.9(68.0 ; 143.3) \\
P_{1-2}<0.01\end{array}$ & $\begin{array}{l}276.5(257.0 ; 354.5) \\
\mathrm{P}_{1-3}>0.05 \\
\mathrm{P}_{2-3}<0.01\end{array}$ \\
\hline hsCRP, mg/L & $7.4(4.9 ; 10.3)$ & $\begin{array}{l}2.4(0.9 ; 3.3) \\
P_{1-2}<0.01\end{array}$ & $\begin{array}{l}6.9(5.0 ; 8.5) \\
P_{1-3}>0.05 \\
P_{2-3}<0.01\end{array}$ \\
\hline
\end{tabular}

$P_{1.2}$ : the value of $p$ between groups 1 and $2 ; P_{1.3}$; the value of $p$ between groups 1 and $3 ; P_{2.3}$ : the value of $p$ between groups 2 and 3 .

Table 2. IMC thickness in the studied groups, $\mathrm{n}(\%)$

\begin{tabular}{|c|c|c|c|}
\hline IMC thickness, mm & Group $1(n=72)$ & Group $2(n=50)$ & Group $3(n=20)$ \\
\hline$\geq 0.9 \mathrm{~mm}, \mathrm{n}(\%)$ & $65(90.3)$ & $\begin{array}{l}37(74.0) \\
P_{1-2}<0.05\end{array}$ & $\begin{array}{l}7(35.0) \\
P_{1-3}<0.01 \\
P_{2-3}<0.01\end{array}$ \\
\hline$<0.9 \mathrm{~mm}, \mathrm{n}(\%)$ & $7(9.7)$ & $\begin{array}{l}13(26.0) \\
P_{1-2}<0.05\end{array}$ & $\begin{array}{l}13(65.0) \\
P_{1-3}<0.01 \\
P_{2-3}<0.01\end{array}$ \\
\hline
\end{tabular}

$P_{1-2}$ : the value of $p$ between groups 1 and $2 ; P_{1-3}$; the value of $p$ between groups 1 and $3 ; P_{2.3}$ : the value of $p$ between groups 2 and 3 .

In the structure of plaques, isoechoic were significantly more often seen among group 1 patients as compared to group $3\left(X^{2}=6.56, P<0.01\right)$, and hyperechoic - as compared to group $2\left(X^{2}=4.63, P<0.05\right)$. Hypoechoic plaques were detected in groups 1 and 2 with similar frequency $(P>0.05)$. This type of plaque was associated with a high risk of cerebrovascular events.

The patients of all groups were characterized by a mild degree of stenosis, but in group 1, the degree of stenosis were most pronounced than that in groups $2(P<0.01)$ and $3(P<0.01)$. Significant difference $(P>0.05)$ was not found between groups in terms of the calcified plaques prevalence, as their frequency in all groups was low.

In the patients with arterial hypertension and gout, a significant moderate positive correlation was found between the IMC thickness and the serum UA level $\left(r_{s}=0.46\right.$, 
Table 3. Frequency of detection and general characteristics of atherosclerotic plaques in the studied groups of patients, Me (Q25; Q75), $n$ (\%)

\begin{tabular}{|c|c|c|c|}
\hline $\begin{array}{l}\text { Indicator, units of } \\
\text { measurement }\end{array}$ & Group $1(n=72)$ & Group $2(n=50)$ & Group $3(n=20)$ \\
\hline $\begin{array}{l}\text { Atherosclerotic plaques } \\
\text { detected, } \mathrm{n}(\%)\end{array}$ & $53(73.6)$ & $\begin{array}{l}23(46.0) \\
P_{1-2}<0.01\end{array}$ & $\begin{array}{l}7(35.0) \\
P_{1-3}<0.01 \\
P_{2-3}>0.05\end{array}$ \\
\hline \multicolumn{4}{|l|}{ Plaque echogenicity, $n(\%)$ : } \\
\hline isoechoic & $32(44.4)$ & $\begin{array}{l}16(32.0) \\
P_{1-2}>0.05\end{array}$ & $\begin{array}{l}2(10.0) \\
P_{1-3}<0.01 \\
P_{2-3}>0.05\end{array}$ \\
\hline hyperechoic & $18(25.0)$ & $\begin{array}{l}5(10.0) \\
P_{1-2}<0.05\end{array}$ & $\begin{array}{l}5(25.0) \\
P_{1-3}>0.05 \\
P_{2-3}>0.05\end{array}$ \\
\hline hypoechoic & $3(4.2)$ & $\begin{array}{l}2(4.0) \\
P_{1-2}>0.05\end{array}$ & $\begin{array}{l}0(0.0) \\
P_{1-3}>0.05 \\
P_{2-3}>0.05\end{array}$ \\
\hline The degree of stenosis, $\%$ & $20.0(0.0 ; 25.0)$ & $\begin{array}{l}10.6(0.0 ; 20.0) \\
P_{1-2}<0.01\end{array}$ & $\begin{array}{l}10.0(0.0 ; 25.0) \\
\mathrm{P}_{1-3}<0.01 \\
\mathrm{P}_{2-3}>0.05\end{array}$ \\
\hline $\begin{array}{l}\text { Calcified atherosclerotic } \\
\text { plaque, } n(\%)\end{array}$ & $4(5.6)$ & $\begin{array}{l}1(2.0) \\
P_{1-2}>0.05\end{array}$ & $\begin{array}{l}2(10.0) \\
P_{1-3}>0.05 \\
P_{2-3}>0.05\end{array}$ \\
\hline
\end{tabular}

$P_{1-2}$ : the value of $p$ between groups 1 and $2 ; P_{1-3}$; the value of $p$ between groups 1 and $3 ; P_{2 \cdot 3}$ : the value of $\mathrm{p}$ between groups 2 and 3 .

$P<0.01), \operatorname{hsCRP}\left(r_{s}=0.33, P<0.01\right)$, age $\left(r_{s}=0.33\right.$, $P<0.01)$, duration of gout $\left(r_{s}=0.27, P<0.05\right)$ and the VAS $\left(r_{s}=0.39, P<0.01\right)$; the level of hsCRP was correlated with the presence of atherosclerotic plaques $(\tau=+0.64, P<0.05)$ in hypertensive patients with gout. The serum UA level was involved in the processes of vascular remodeling.

\section{Discussion}

The results of our study showed that comorbidity of hypertension and gout contributed to the increase in the detection rate of IMC thickness $\geq 0.9 \mathrm{~mm}$ and atherosclerotic plaques in comparison with patients, who had only hypertension or gout.

This mutual relationship between hypertension and gout can be explained by common pathogenetic mechanisms of development. For example, hypertensive patients demonstrate an increase in hsCRP, adhesion molecules, chemokines, pro-inflammatory cytokines. The above key points emphasize the role of cytokines as early inflammatory mediators and potential stimulators of the hypertension pathogenesis. It is known that such mechanisms underlie the pathogenesis of gout.

We found the significant positive correlation between the IMC thickness and the serum levels of UA, hsCRP, despite controversial previous data on this topic. Ramirez et al. $[11,12]$ reported an independent association between UA and the IMC thickness, while Songand et al. $[13,14]$ did not find such a correlation, which may be related to different characteristics of the sample and the methodological approaches chosen.

Several studies have examined the relation between UA and carotid plaques. Research conducted by Neogi et al. with participation of 4866 Americans without risk factors associated with cardiovascular disease and hyperuricemia demonstrated an independent association between UA and carotid plaque in men, but not in women. In addition, Ishizaka et al. showed a higher prevalence of carotid plaques in the second (321-363 mg/dL), third (369-416 $\mathrm{mg} / \mathrm{dL}$ ) and fourth (423-655 mg/dL) quartiles of serum UA concentration among 8144 examined individuals without metabolic syndrome, while they did not find such an association in men with metabolic syndrome, or in women in general [15].

The results of our study coincide with the data on the higher prevalence of atherosclerotic plaques in hypertensive patients with gout, but in our case, this frequency does not depend on sex, because the study included only male patients. It is important that the results of our study relate to patients with comorbid pathology, who have cardiovascular risk factors.

The establishment of the associations described above is aimed at determining a certain category of patients with specific characteristics (male sex, comorbid pathology, hyperuricemia, dyslipidemia, hyperferitinemia, increased hsCRP level), who should be advised to undergo ultrasound of the neck vessels by family doctors for early detection of atherosclerotic lesions and timely prescription of appropriate treatment.

\section{Conclusions}

1. The duration of arthritis and the last exacerbation of gout, the pain intensity on the VAS scale were associated with a more severe course of gout combined with hypertension.

2. The patients with comorbidity of hypertension and gout were diagnosed with more severe disorders of purine and lipid metabolism, increased inflammatory markers (ferritin and hsCRP) as compared to the patients with gout or hypertension alone, that should be considered not only in the aspect of chronic inflammation, but also as a part of the disease.

3. The proportion of patients with IMC thickness $\geq 0.9 \mathrm{~mm}$ and the incidence of atherosclerotic plaques in patients with comorbid pathology (hypertension and gout) were significantly higher than those in patients with only hypertension $(P<0.01)$ or gout $(P<0.01)$, indicating that hypertension and gout share pathogenetic mechanisms worsening the course of both diseases.

The perspective for the further scientific research. To evaluate the effectiveness of treatment in variable characteristics of atherosclerotic plaque among patients with comorbid pathology.

Conflicts of interest: authors have no conflict of interest to declare. Конфлікт інтересів: віАсутній.

Надійшла Ао редакції / Received: 29.03.2021

Після Аоопрацювання / Revised: 19.04.2021

Прийнято АО Аруку / Accepted: 23.04.2021

Information about authors:

Kuzmina H. P., MD, PhD, DSc, Professor of the Department of Therapy, Cardiology and Family Medicine, the Faculty of Postgraduate Education, Dnipro State Medical University, Kryvyi Rih, Ukraine.

ORCID ID: 0000-0003-4556-4013

Lazarenko 0. M., MD, PhD, Assistant of the Department of Therapy, Cardiology and Family Medicine, the Faculty of Postgraduate Education, Dnipro State Medical University, Kryvyi Rih, Ukraine. ORCID ID: 0000-0002-7806-2661 


\section{Відомості про авторів:}

Кузьміна Г. П., А-р меА. наук, професор каф. терапії, карАіології та сімейної меАицини факультету післядипломної освіти, Аніпровський Аержавний медичний університет, м. Кривий Ріг Україна.

^азаренко О. М., А-р філософії, асистентка каф. терапії, кардіології та сімейної медицини факультету післяАипломної освіти, Аніпровський Аержавний меАичний університет, м. Кривий Ріг, Україна.

\section{Сведения об авторах:}

Кузьмина А. П., А-р меА. наук, профессор каф. терапии, карАиологии и семейной меАицины факультета послеАипломного образования, Анепровский государственный меАицинский университет, г. Кривой Рог, Украина. Лазаренко О. Н., А-р философии, ассистент каф. терапии, кардиологии и семейной меАицины факультета послеАипломного образования, Анепровский госуАарственный медицинский университет, г. Кривой Рог, Украина.

\section{References}

[1] Joo, H. J., Kim, G. R., Choi, D. W., Joo, J. H., \& Park, E. C. (2020). Uric acid level and kidney function: a cross-sectional study of the Korean national health and nutrition examination survey (2016-2017). Scientific Reports, 10(1), Article 21672. https://doi.org/10.1038/ s41598-020-77702-X

[2] Wu, A. H., Gladden, J. D., Ahmed, M., Ahmed, A., \& Filippatos, G. (2016). Relation of serum uric acid to cardiovascular disease. International Journal of Cardiology, 213, 4-7. https://doi.org/10.1016/i. ijcard.2015.08.110

[3] Badimon, L., Peña, E., Arderiu, G., Padró, T., Slevin, M., Vilahur, G., \& Chiva-Blanch, G. (2018). C-Reactive Protein in Atherothrombosis and Angiogenesis. Frontiers in Immunology, 9, Article 430. https://doi. org/10.3389/immu.2018.00430

[4] Franceschini, N. Giambartolomei, C. de Vries, P. S. Finan, C. Bis, J. C., Huntley, R. P., Lovering, R. C., Tajuddin, S. M., Winkler, T. W., Graff, M., Kavousi, M., Dale, C., Smith, A. V., Hofer, E., van Leeuwen, E. M., Nolte, I. M., Lu, L., Scholz, M., Sargurupremraj, M., Pitkänen, N., ... O'Donnell, C. J. (2018). GWAS and colocalization analyses implicate carotid intima-media thickness and carotid plaque loci in cardiovascular outcomes. Nature Communications, 9(1), Article 5141. https://doi.org/10.1038/s41467-018-07340-5

[5] Plasencia Martínez, J. M., \& García Santos, J. M. (2017). Is manual ultrasonographic measurement of carotid intima-media thickness a reproducible cardiovascular biomarker? Es la medida ecográfica manual del grosor íntima-media carotídeo un biomarcador cardiovascular reproducible? Radiologia, 59(6), 478-486. https://doi.org/10.1016/i.rx.2017.07.001

[6] Xiong, X. D., Xiong, W. D. Xiong, S. S., \& Chen, G. H. (2017). Research Progress on the Risk Factors and Outcomes of Human Carotid Atherosclerotic Plaques. Chinese Medical Journal, 130(6), 722-729. https://doi.org/10.4103/0366-6999.201598

[7] Poredos, P., Gregoric, I. D., \& Jezovnik, M. K. (2020). Inflammation of carotid plaques and risk of cerebrovascular events. Annals of Translational Medicine, 8(19), Article 1281. https://doi.org/10.21037/atm-2020-cass-15

[8] Williams, B., Mancia, G., Spiering, W., Agabiti Rosei, E., Azizi, M., Burnier, M., Clement, D. L., Coca, A., de Simone, G., Dominiczak, A., Kahan, T., Mahfoud, F., Redon, J., Ruilope, L., Zanchetti, A., Kerins, M., Kjeldsen, S. E., Kreutz, R., Laurent, S., Lip, G., ... ESC Scientific Document Group. (2018). $2018 \mathrm{ESC} / \mathrm{ESH}$ Guidelines for the management of arterial hypertension. European Heart Journal, 39(33), 3021-3104. https://doi.org/10.1093/eurhearti/ehy339

[9] Janssens, H., Fransen, J., Janssen, M., Neogi, T., Schumacher, H. R., Jansen, T. L., Dalbeth, N., \& Taylor, W. J. (2017). Performance of the 2015 ACR-EULAR classification criteria for gout in a primary care population presenting with monoarthritis. Rheumatology, 56(8), 13351341. https://doi.org/10.1093/rheumatology/kex 164

[10] Neogi, T., Jansen, T. L., Dalbeth, N., Fransen, J., Schumacher, H. R. Berendsen, D., Brown, M., Choi, H., Edwards, N. L., Janssens, H. J., Lioté, F., Naden, R. P., Nuki, G., Ogdie, A., Perez-Ruiz, F., Saag, K., Singh, J. A., Sundy, J. S., Tausche, A. K., Vaquez-Mellado, J., ... Taylor, W. J. (2015). 2015 Gout classification criteria: an American College of Rheumatology/European League Against Rheumatism collaborative initiative. Annals of the Rheumatic Diseases, 74(10), 1789-1798. https:// doi.org/10.1136/annrheumdis-2015-208237

[11] Ramirez, A. J., Christen, A. I., \& Sanchez, R. A. (2018). Serum Uric Acid Elevation is Associated to Arterial Stiffness in Hypertensive Patients with Metabolic Disturbances. Current Hypertension Reviews, 14(2), 154-160. https://doi.org/10.2174/1573402114666180413143312
[12] Canepa, M. Viazzi, F. Strait, J. B. Ameri, P., Pontremoli, R., Brunelli, C., Studenski, S., Ferrucci, L., Lakatta, E. G., \& AIGhatrif, M. (2017). Longitudinal Association Between Serum Uric Acid and Arterial Stiffness: Results From the Baltimore Longitudinal Study of Aging. Hypertension, 69(2), 228-235. https://doi.org/10.1161/HYPERTENSIONAHA. 116.08114

[13] Song, M., Li, N., Yao, Y., Wang, K., Yang, J., Cui, Q., Geng, B., Chen, J., Wang, Y., Cheng, W., \& Zhou, Y. (2019). Longitudinal association between serum uric acid levels and multiterritorial atherosclerosis. Journal of Cellular and Molecular Medicine, 23(8), 4970-4979. https:ll doi.org/10.1111/jcmm. 14337

[14] An, L. N., Rong, N., Ning, M., Feng, L. L., Chen, Z. H., Liu, W. Q., Ouyang, X. C., Diao, F. R., Han, Z. G., \& Hong, J. (2020). High serum uric acid is associated with increased arterial stiffness in hypertension. Aging, 12(14), 14569-14581. https://doi.org/10.18632/aging.103506

[15] Drivelegka, P., Forsblad-d'Elia, H., Angerås, O., Bergström, G., Schmidt, C., Jacobsson, L., \& Dehlin, M. (2020). Association between serum level of urate and subclinical atherosclerosis: results from the SCAPIS Pilot. Arthritis Research \& Therapy, 22(1), Article 37. https://doi.org/10.1186/s13075-020-2119-0 